\title{
Decreased Incidence of Hepatocellular Carcinoma after Directly Acting Antiviral Therapy in Patients with Hepatitis C-Related Advanced Fibrosis and Cirrhosis
}

\author{
Shimaa Kilany' \\ Lmyaa Ata' \\ Asmaa Gomaa (1D) \\ Aliaa Sabry' \\ Ali Nada' \\ El-Sayed Tharwa' \\ Gamal Badra' \\ Ashraf Abogabal' \\ Mohamed Elwaraky ${ }^{2}$ \\ Enas Moaz ${ }^{3}$ \\ Sameera Ezzat ${ }^{3}$ \\ Ahmed Elsharawy ${ }^{4}$ \\ Imam Waked (D) \\ 'Hepatology and Gastroenterology \\ Department, National Liver Institute, \\ Menoufia University, Menoufia, Egypt; \\ ${ }^{2}$ Radiology Department, National Liver \\ Institute, Menoufia University, Menoufia, \\ Egypt; ${ }^{3}$ Epidemiology Department, \\ National Liver Institute, Menoufia \\ University, Menoufia, Egypt; ${ }^{4}$ Clinical \\ Pathology Department, National Liver \\ Institute, Menoufia University, Menoufia, \\ Egypt
}

Background and Aim: Existing data are controversial regarding the incidence of hepatitis $\mathrm{C}$ (HCV)-related hepatocellular carcinoma (HCC) following directly acting antiviral (DAA) therapy. This prospective study aimed to assess incidence, and risk factorss of HCC following DAA therapy in patients with HCV-related advanced fibrosis (F3) and cirrhosis (F4).

Methods: Incidence of HCC was calculated in 1,630 patients with HCV-related F3 and F4 treated with DAA prospectively followed for up to 43 months in a single tertiary referral center and compared to historical controls. Risk factors of incident HCC were also determined.

Results: The crude outcome rate was $2.15 / 100$ person-years, significantly lower than a similar historical cohort (5.57/100 person-years). Risk of developing HCC was higher with the presence of cirrhosis (F4 vs F3, AHR 3.59) and treatment failure (vs achieving SVR, AHR 3.37). Presence of decompensated cirrhosis, platelet count $<100 \times 10^{3} / \mathrm{mL}$, and high AFP were independent risk factors of developing HCC.

Conclusion: Incidence of HCC was significantly lower in patients with HCV-related advanced fibrosis and cirrhosis treated with DAAs than in a historical cohort of untreated patients. Decompensated cirrhosis, baseline AFP $\geq 10 \mathrm{ng} / \mathrm{mL}$, diabetes, and nonresponse to DAA were independent risk factors of incident HCC.

Keywords: HCC, DAA, HCC incidence, HCC predictors, HCC characteristics

\section{Introduction}

Chronic hepatitis $\mathrm{C}$ virus (HCV) infection has been identified as an independent risk factor of hepatocellular carcinoma (HCC) development, especially in patients with cirrhosis. ${ }^{1}$ The risk of HCC development in HCV-related cirrhosis is estimated at $2 \%-8 \%$ per year, ${ }^{2}$ which further increases with age, male sex, alcohol misuse, and coinfection with hepatitis B or HIV. ${ }^{3,4}$

Multiple studies have provided evidence that achieving sustained virological response (SVR) after IFN therapy is associated with a fourfold reduction in HCC risk. $^{5}$ Nevertheless, most patients with cirrhosis are not candidates for IFN therapy, and the risk of HCC persists in cirrhosis even after SVR, especially in elderly patients. ${ }^{6,7}$ Since the introduction of directly acting antivirals (DAAs), tremendous advancement in the treatment of HCV patients has occurred, with SVR rates $>90 \%$ in real-life settings ${ }^{8-11}$ and excellent safety profiles, which has enabled their use
Correspondence: Imam Waked University, Shebeen El-Kom, Menoufia, Egypt

Tel +20-12-22I5-7256

Fax +20-48-2234586

Email iwaked@liver-eg.org 
even in patients with decompensated liver disease, who had not been eligible for IFN-based regimens. ${ }^{12}$ Patients with cirrhosis who reach a DAA-induced SVR have shown lower rates of cirrhosis progression and downstream complications, especially decompensation, and all-cause mortality. $^{13}$

Owing to the unprecedentedly high antiviral efficacy of DAAs, it was anticipated that the risk of HCC would be reduced. Several reports have suggested more frequent post-DAA HCC development and recurrence, and a DAAinduced HCC-preventive effect has been debated. ${ }^{14-16}$ Other studies have not shown increased risk, with followup periods reaching 15 months. ${ }^{17}$ As such, the impact of DAA therapy on HCC incidence remains controversial.

Data from Egypt have suggested an increase in recurrent $\mathrm{HCC}$ following DAA treatment, ${ }^{18}$ but reports evaluating the incidence of de novo HCC after DAA treatment in HCV genotype 4 (HCV-G4) are limited.

In this study, we prospectively evaluated a cohort of patients with HCV G4-related cirrhosis or advanced fibrosis without previous diagnosis of $\mathrm{HCC}$ who had received DAA treatment, in order to assess HCC incidence, and identify predictive risk factors associated with $\mathrm{HCC}$ occurrence.

\section{Methods}

\section{Study Cohort}

This study included HCV-G4 patients 18 years or older with advanced fibrosis or cirrhosis who had received DAA treatment during 2016 at a single tertiary referral center in Egypt. They were prospectively followed every 3 months after treatment to assess incidence of HCC. Patients with hepatitis B coinfection or with HCC prior to starting DAA treatment were excluded.

The study was approved by the Ethics Committee of the National Liver Institute (IRB00003413) and performed in accordance with the 1975 Declaration of Helsinki. All authors had access to the study data and reviewed and approved the final manuscript.

\section{Assessment of Patients' Baseline and Treatment-Related Parameters}

Fibrosis was assessed by calculating Fibrosis4 (FIB-4) index scores (age [years] $\times$ AST [U/L]/platelet count $\left.\left[\times 10^{9} / \mathrm{L}\right] \times \operatorname{ALT}[\mathrm{U} / \mathrm{L}]\right)^{19,20}$ and measuring liver stiffness by transient elastography using a FibroScan (Echosens, Paris, France) before DAA therapy. Advanced fibrosis was considered liver stiffness of $>9.5-12.5 \mathrm{kPa}$, and cirrhosis was defined based on clinical features, ultrasonography, or liver stiffness $>12.5 \mathrm{kPa}^{21}$ All patients underwent abdominal ultrasound (and multislice triphasic CT scan if needed) to exclude presence of any focal lesion in the liver before the start of treatment.

Virological response to DAA therapy was assessed, and sustained virological response (SVR) was defined as having undetectable HCV RNA for 12 weeks or more following completion of treatment.

\section{Outcome Events}

The study outcome was first occurrence of HCC up to the end of June of 2019. Patients had liver ultrasound performed every 3 months or whenever new symptoms appeared. Although international guidelines recommend ultrasound screening for HCC every 6 months in followup of patients with cirrhosis, in this study the 3-month interval was due to the yet-unknown and possible increased risk of HCC after the use of DAAs. The low cost of ultrasound in our setting, added to the costeffectiveness of screening for HCC based on our previously published results, ${ }^{23}$ made screening using ultrasound every 3 months feasible and more reasonable for these patients. HCC was suspected based on ultrasound imaging and diagnosed according to current European Association for the Study of the Liver-European Organisation for Research and Treatment of Cancer guidelines by one dynamic imaging technique with triphasic CT scanning or dynamic contrast-enhanced MRI meeting the criteria typical of HCC (hypervascularity in the arterial phase with washout in the portal venous or delayed phases). ${ }^{22}$ Duration of follow-up was calculated from the end of DAA therapy till diagnosis of HCC or end of follow-up. The date of HCC diagnosis was used as a surrogate for time of $\mathrm{HCC}$ occurrence.

The crude annual incidence of HCC development was calculated and categorized by fibrosis stage and SVR status. This was compared to the annual incidence of HCC in 1,254 patients with $\mathrm{HCV}$ cirrhosis followed before the era of DAA therapy who were not suitable for IFN therapy. These patients were prospectively followed up with liver ultrasound and AFP measurement every 6 months. ${ }^{23}$

\section{Predictor Variables}

The probability of HCC development was determined for baseline covariates. Cox's proportional- hazard model was used to identify risk factors associated with incident HCC. 
Table I Baseline Demographic and Clinical Characteristics of HCV Patients Treated with Direct Acting Antiviral Agents (Overall and by Sustained Virological Response

\begin{tabular}{|c|c|c|c|c|c|}
\hline \multicolumn{2}{|l|}{ Characteristics } & \multirow{2}{*}{$\begin{array}{c}\begin{array}{c}\text { Overall } \\
\mathbf{n}=1,630\end{array} \\
55.1 \pm 8.32 \\
55.0\end{array}$} & \multirow{2}{*}{$\begin{array}{c}\begin{array}{c}\text { SVR } \\
\mathbf{n}=\mathbf{I , 5 3} \mathbf{I}\end{array} \\
\begin{array}{c}54.5 \mathrm{I} \pm 8.20 \\
55.0\end{array}\end{array}$} & \multirow{2}{*}{$\begin{array}{c}\begin{array}{c}\text { No SVR } \\
\mathbf{n}=97\end{array} \\
53.8 \pm 9.9 \\
54.0\end{array}$} & \multirow{2}{*}{$\begin{array}{c}P^{\mathbf{b}} \\
0.32\end{array}$} \\
\hline Age & $\begin{array}{l}\text { Mean } \pm \text { SD } \\
\text { Median }\end{array}$ & & & & \\
\hline Sex, n (\%) & $\begin{array}{l}\text { Male } \\
\text { Female }\end{array}$ & $\begin{array}{c}\text { I, I } 85 \text { (72.7) } \\
445(27.3)\end{array}$ & $\begin{array}{c}\text { I, I IO (93.8) } \\
42 \text { I (94.8) }\end{array}$ & $\begin{array}{l}74(6.2) \\
23(5.2)\end{array}$ & 0.42 \\
\hline Diabetes, n (\%) & $\begin{array}{l}\text { No } \\
\text { Yes }\end{array}$ & $\begin{array}{c}1,324(81.2) \\
306(18.8)\end{array}$ & $\begin{array}{c}1,254(94.8) \\
277(90.8)\end{array}$ & $\begin{array}{l}69(5.2) \\
28(9.2)\end{array}$ & 0.008 \\
\hline Ascites, n (\%) & $\begin{array}{l}\text { Yes } \\
\text { No }\end{array}$ & $\begin{array}{c}112(6.9) \\
1,518(93.1)\end{array}$ & $\begin{array}{c}106(95.5) \\
\mathrm{I}, 425(93.9)\end{array}$ & $\begin{array}{c}5(4.5) \\
92(6.1)\end{array}$ & 0.50 \\
\hline Previous HCV antiviral treatment, $\mathrm{n}(\%)$ & $\begin{array}{l}\text { No } \\
\text { Yes, with IFN } \\
\text { Yes, with DAA }\end{array}$ & $\begin{array}{c}\text { I,458 (89.4) } \\
80(4.9) \\
92(5.6)\end{array}$ & $\begin{array}{c}\text { I,362 (93.5) } \\
79(98.8) \\
90(97.8)\end{array}$ & $\begin{array}{c}94(6.5) \\
I(1.2) \\
2(2.2)\end{array}$ & $0.04 *$ \\
\hline ALT (IU/L) & $\begin{array}{l}\text { Mean } \pm \text { SD } \\
\text { Median }\end{array}$ & $\begin{array}{c}62.1 \pm 40.4 \\
52.0\end{array}$ & $\begin{array}{c}61.7 \pm 40.2 \\
51.0\end{array}$ & $\begin{array}{c}67.1 \pm 42.3 \\
59.0\end{array}$ & 0.10 \\
\hline AST (IU/L) & $\begin{array}{l}\text { M } \pm \text { SD } \\
\text { Median }\end{array}$ & $\begin{array}{c}63.3 \pm 38.3 \\
55.0\end{array}$ & $\begin{array}{c}63.2 \pm 38.9 \\
55.0\end{array}$ & $\begin{array}{c}64.3 \pm 28.4 \\
59.0\end{array}$ & 0.13 \\
\hline AFP (IU/L) & $\begin{array}{l}\text { Mean } \pm \text { SD } \\
\text { Median }\end{array}$ & $\begin{array}{c}15.6 \pm 22.9 \\
8.0\end{array}$ & $\begin{array}{c}15.5 \pm 22.8 \\
8.0\end{array}$ & $\begin{array}{c}17.3 \pm 25.2 \\
8.9\end{array}$ & 0.59 \\
\hline Platelets, $\times 10^{3} / \mathrm{mm}^{3}$ & $\begin{array}{l}\text { Mean } \pm \text { SD } \\
\text { Median }\end{array}$ & $\begin{array}{c}|54.6 \pm 6| .4 \\
\mid 48.0\end{array}$ & $\begin{array}{c}|54.2 \pm 6| .4 \\
\mid 47.0\end{array}$ & $\begin{array}{c}160.5 \pm 60.7 \\
150.0\end{array}$ & $0.36 * *$ \\
\hline Total bilirubin (mg/dL) & $\begin{array}{l}\text { Mean } \pm \text { SD } \\
\text { Median }\end{array}$ & $\begin{array}{c}I .1 \mathrm{I} \pm 0.75 \\
0.9\end{array}$ & $\begin{array}{c}\text { I. } 10 \pm 0.72 \\
0.9\end{array}$ & $\begin{array}{c}1.25 \pm 1.07 \\
0.9\end{array}$ & 0.18 \\
\hline Albumin $(g / d L)$ & $\begin{array}{l}\text { Mean } \pm \text { SD } \\
\text { Median }\end{array}$ & $\begin{array}{c}3.8 I \pm 0.49 \\
3.8\end{array}$ & $\begin{array}{c}3.82 \pm 0.49 \\
3.8\end{array}$ & $\begin{array}{c}3.77 \pm 0.47 \\
3.8\end{array}$ & $0.32 * *$ \\
\hline INR & $\begin{array}{l}\text { Mean } \pm \text { SD } \\
\text { Median }\end{array}$ & $\begin{array}{c}\text { I. } 13 \pm 0.28 \\
\text { I.I }\end{array}$ & $\begin{array}{c}1.13 \pm 0.28 \\
\text { I.I }\end{array}$ & $\begin{array}{c}1.14 \pm 0.21 \\
1.1\end{array}$ & 0.23 \\
\hline Child-Turcotte-Pugh class, ${ }^{c}$ n (\%) & $\begin{array}{l}A \\
B \\
C\end{array}$ & $\begin{array}{c}973(81.2) \\
217(18.1) \\
9(0.8)\end{array}$ & $\begin{array}{c}913(93.8) \\
202(93.5) \\
7(77.8)\end{array}$ & $\begin{array}{l}60(6.2) \\
14(6.5) \\
2(22.2)\end{array}$ & $0.14 *$ \\
\hline Initial FIB-4 score, n (\%) & $\begin{array}{l}<1.45 \\
1.45-3.25 \\
>3.25\end{array}$ & $\begin{array}{l}205(12.6) \\
697(42.8) \\
728(44.6)\end{array}$ & $\begin{array}{l}I 87(91.2) \\
66 \mid(94.8) \\
683(94.1)\end{array}$ & $\begin{array}{l}18(8.8) \\
36(5.3) \\
43(5.9)\end{array}$ & 0.16 \\
\hline DAA regimen ${ }^{d}$ & $\begin{array}{l}\text { Sof-Rbv } \\
\text { Sof-PEG-Rbv } \\
\text { Sof-Smv } \\
\text { Sof-Smv-Rbv } \\
\text { Sof-Dcv } \\
\text { Sof-Dcv-Rbv } \\
\text { Sof-Ldv } \\
\text { Sof-Ldv-Rbv } \\
\text { PRO-Rbv }\end{array}$ & $\begin{array}{c}158(9.7) \\
82(5) \\
116(7.1) \\
518(31.8) \\
185(11.4) \\
329(20.2) \\
89(5.5) \\
120(7.4) \\
21(1.3)\end{array}$ & $\begin{array}{l}126(79.7) \\
70(85.4) \\
113(97.4) \\
497(95.9) \\
176(95.1) \\
319(97) \\
86(96.6) \\
114(95) \\
20(95.2)\end{array}$ & $\begin{array}{c}32(20.3) \\
12(14.6) \\
3(2.6) \\
21(4.1) \\
9(4.9) \\
10(3) \\
3(3.4) \\
6(5) \\
1(4.8)\end{array}$ & $<0.001$ \\
\hline
\end{tabular}

Notes: ${ }^{\mathrm{a}}$ Two patients died before SVRI2; ${ }^{\mathrm{b}}$ comparison between patients with SVR and patients without; ${ }^{\mathrm{c}}$ data for I, 199 patients with cirrhosis; ${ }^{\mathrm{d} D A A}$ regimen was for 12 weeks, except Sof-Rbv (24 weeks). P-values from Chi-square test ${ }^{2}$ and Mann-Whitney tests. *Fisher's exact test; **t-test.

Abbreviations: ALT, alanine aminotransferase; AST, aspartate aminotransferase; DAA, directly acting antiviral; Dcv, daclatasvir; FIB-4, Fibrosis 4 (index); HCV, hepatitis C virus; INR, international normalized ratio; Ldv, ledipasvir; PRO, paritaprevir-ritonavir-ombitasvir; Rbv, ribavirin; Sof, sofosbuvir; Smv, simeprevir; SVR, sustained virological response. 
Covariates included in this analysis were baseline age, sex, diabetes, platelet count, AFP, ascites, Child-TurcottePugh (CTP) score, FIB-4 score, and change in FIB-4 score following treatment.

\section{Statistical Analysis}

Annual incidence of $\mathrm{HCC}$ in the whole cohort of patients who had completed DAA treatment was calculated. We determined the date of DAA-treatment completion and followed patients to the development of HCC, death, or end of follow-up, whichever was earlier. We calculated incidence with $95 \%$ CIs as the number of HCC events divided by total person-years (PYs) of follow-up.

Incidence rate of HCC development in the subgroup of patients with F4 cirrhosis who did not respond to DAA therapy was compared to historical incidence rate of $\mathrm{HCC}$ development in patients with HCV-related cirrhosis without antiviral therapy before the era of DAAs in the same center. ${ }^{22}$

Cumulative probability of HCC occurrence was determined for each independent variable and compared using Kaplan-Meier curves, with differences between these curves evaluated using the log-rank tests. For KaplanMeier analysis with more than two factors, we used the Bonferroni method, and 0.016 was regarded as significant for this analysis.

We used the multivariate Cox proportional-hazard model to compare the risk factors of HCC in the whole cohort. Unadjusted and adjusted HRs with 95\% CIs were calculated for each independent variable. Statistical analysis was performed using SPSS 20.0 and Stata 14.

\section{Results}

\section{Patient Characteristics}

A total of 1,630 patients with HCV-related advanced fibrosis or cirrhosis starting DAA therapy were prospectively included. Baseline characteristics, treatment regimen received, and virological outcomes of treatment are presented in Table 1. Mean age was $55.1 \pm 8.32$ years, $72.7 \%$ were male, $18.8 \%$ had a history of diabetes, and $10.5 \%$ had previously been treated with antiviral therapy, of whom 92 had had exposure to DAAs. In sum, 1,202 $(73.7 \%)$ patients had cirrhosis and $14.2 \%$ decompensated liver cirrhosis (Table 1).

Ribavirin was administered (600-1,000 mg total daily dose, depending on body weight) to 811 patients. Overall 1,531 patients $(93.9 \%)$ achieved SVRs. Patients who did not achieve SVRs were more likely to be diabetic, have had previous antiviral therapy, and received Sof-Rbv for 24 weeks (Table 1).

A historical cohort of 1,254 patients with HCV-related cirrhosis was compared to this prospective cohort. Mean age was $51.5 \pm 8.7$ years, $38.4 \%$ had CTP A, $61.6 \%$ had decompensated liver cirrhosis, and all had not previously been treated with antiviral therapy.

\section{HCC Development after DAA Treatment}

HCC developed in 66 patients over $22.4 \pm 11.7$ months of follow-up. Cumulative probability of HCC occurrence at $6,12,18,24$, and 36 months was $1.8 \%, 2.4 \%, 4.3 \%, 4.8 \%$, and $4.8 \%$, respectively (Table 2 , Figure $1 \mathrm{~A}$ ).

Patients with cirrhosis had significantly higher incidence of HCC than patients with advanced fibrosis (F3). A total of 63 patients with cirrhosis developed HCC over 2,192.2 PYs' follow-up (2.9 per 100 PYs, 95\% CI 2.33.7), while three HCC cases developed in patients with $\mathrm{F} 3$ in 873.3 PYs' follow-up (0.33 per 100 PYs, 95\% CI 0.111.01; Table 3, Figure 1B). The risk of HCC was 3.6-fold higher in patients with cirrhosis than those with advanced fibrosis (AHR 3.59, 95\% CI 1.10-11.66).

HCC was diagnosed in 55 patients with SVR during 2,866.83 PYs' follow-up (1.91 per 100 PYs, 95\% CI 1.472.49), while eleven patients who did not achieve SVR developed HCC over 196.5 PYs (5.59 per 100 PYs, 95\% CI 3.1-10.1; Table 3, Figure 1C). Patients who failed to

Table 2 Follow-up Data and Outcome Events

\begin{tabular}{|l|l|l|l|}
\hline \multicolumn{2}{|l|}{} & $\begin{array}{l}\text { Prospective } \\
\text { Cohort }\end{array}$ & $\begin{array}{l}\text { Historical } \\
\text { Cohort }\end{array}$ \\
\hline Total persons & 1,630 & 1,254 \\
\hline Total person-years follow-up & $3,065.5$ & $1,830.5$ \\
\hline $\begin{array}{l}\text { Number of } \\
\text { outcome events } \\
\text { (HCC } \\
\text { occurrence) }\end{array}$ & $\begin{array}{l}\text { Total } \\
\leq 24 \text { weeks } \\
\text { follow-up } \\
>24 \text { weeks } \\
\text { follow-up }\end{array}$ & 66 & $\begin{array}{l}102 \\
27\end{array}$ \\
\hline $\begin{array}{l}\text { Follow-up } \\
\text { duration (months) }\end{array}$ & $\begin{array}{l}\text { Range } \\
\text { Median }\end{array}$ & $1-43$ & 66 \\
\hline $\begin{array}{l}\text { Crude outcome rate per I00-person } \\
\text { years (95\% Cl) }\end{array}$ & $\begin{array}{l}2.15(1.69- \\
2.74)\end{array}$ & $\begin{array}{l}5.57(4.54- \\
6.76)\end{array}$ \\
\hline \multicolumn{2}{|l|}{$\begin{array}{l}\text { Difference in outcome rate per 100- } \\
\text { person years (95\% Cl) }\end{array}$} & $3.42 \%(2.25 \%-4.59 \%)$ \\
\hline
\end{tabular}

Abbreviations: DAA, directly acting antiviral; HCC, hepatocellular carcinoma. 
A

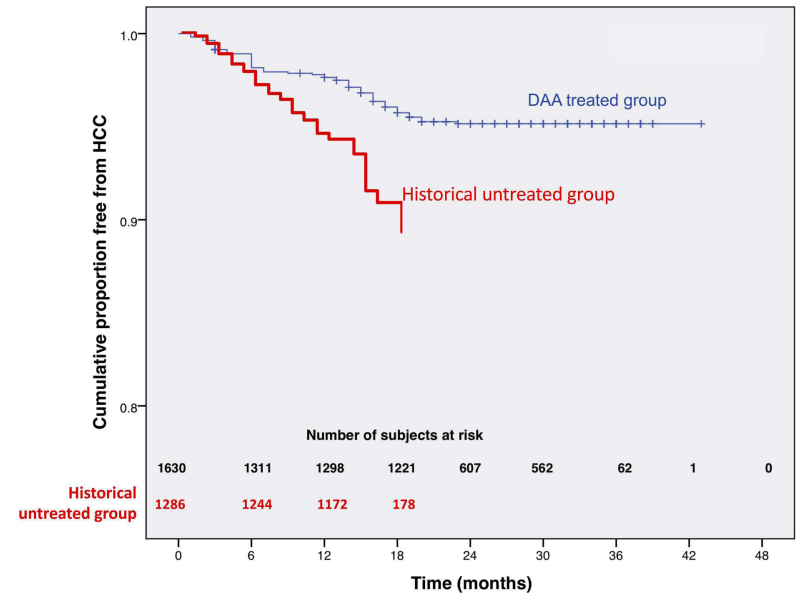

C

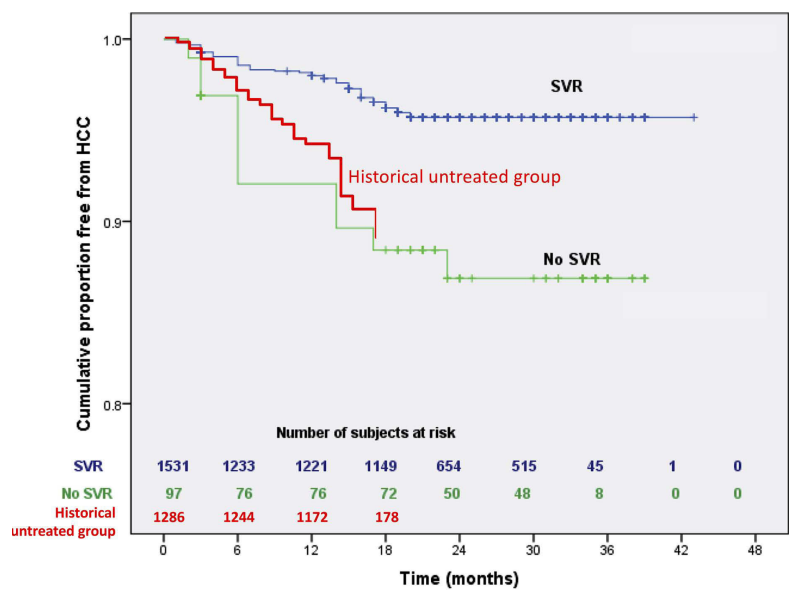

B

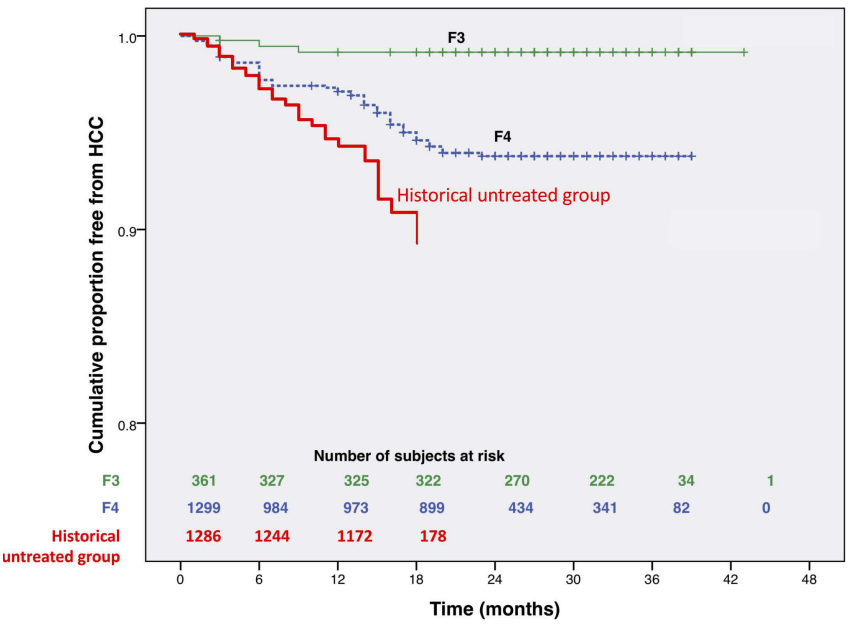

D

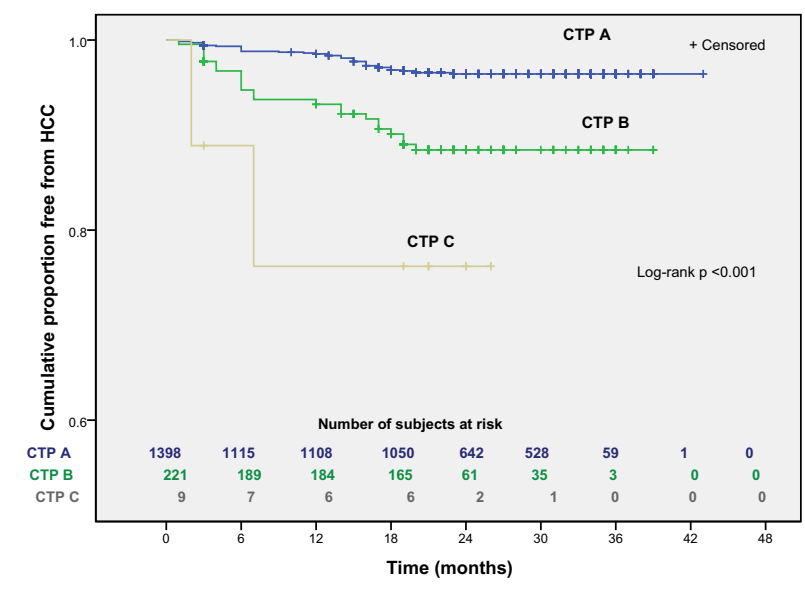

Figure I Continued.

respond to treatment had a 3.4\% increased risk (AHR 3.37, 95\% CI 1.75-6.52; $\mathrm{P}<0.001$; Tables 4 and 5).

Compared to the historical cohort of untreated patients with HCV-related cirrhosis (Table 2), incidence in patients with cirrhosis treated with DAAs who achieved SVR was significantly lower (2.84 per 100 PYs, $95 \%$ CI $1.19-4.39$ vs 5.57 per 100 PYs, 95\% CI 4.54-6.76; difference 3.42 per 100 PYs, 95\% CI 2.25-4.59), but not different in patients who did not achieve SVR (5.59 per 100 PYs, $95 \%$ CI 3.10 10.10 vs 5.57 per 100 PYs, 95\% CI 4.54-6.76; difference -0.02 per $100 \mathrm{PYs}, 95 \% \mathrm{CI}-1.37$ to 1.33 ).

\section{Factors Associated with Risk of HCC in the Whole Cohort}

The cumulative probability of developing HCC increased significantly with decompensated liver disease (Tables 4 and 5, Figure 1D), presence of ascites, low platelet count $\left(<100 \times 10^{3} / \mathrm{mL}\right)$, high AFP (Figure 1E), and presence of DM (Figure 1F). Patients with high initial FIB-4 scores had significantly higher probability of HCC occurrence (Tables 4 and 5, Figure 1G). Patients with cirrhosis assessed by FIB- 4 score $\geq 3.25$ in whom FIB-4 score decreased posttreatment to $<3.25$ had significantly lower cumulative probability of developing HCC during followup than those for whom the FIB-4 scores did not improve posttreatment.

\section{Discussion}

$\mathrm{HCV}$-induced liver fibrosis is a well-established risk factor of $\mathrm{HCC}$ development, ${ }^{2}$ with cumulative HCC risk among patients with cirrhosis of 5\%-30\% within 5 years. ${ }^{24}$ In Egypt, a systematic review of 13 studies that included 
$\mathbf{E}$

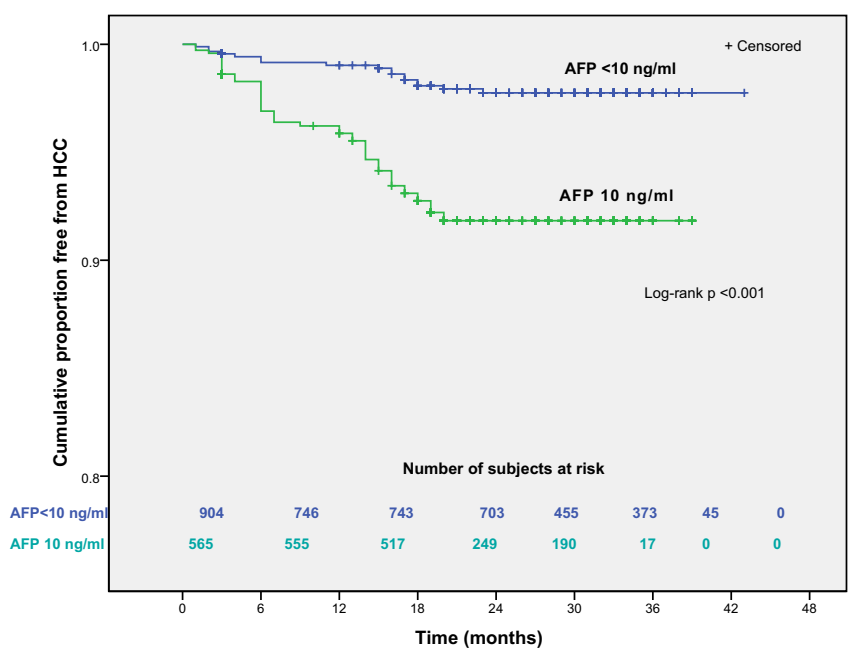

$\mathbf{F}$

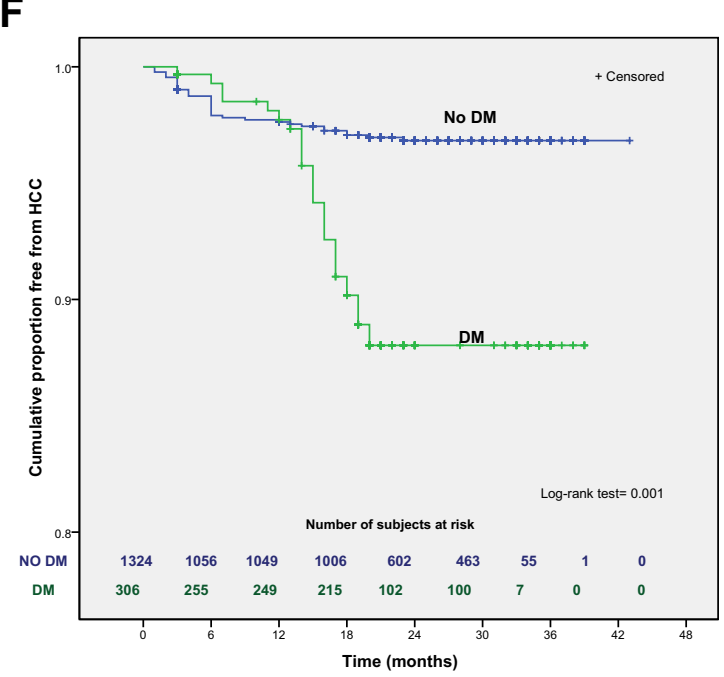

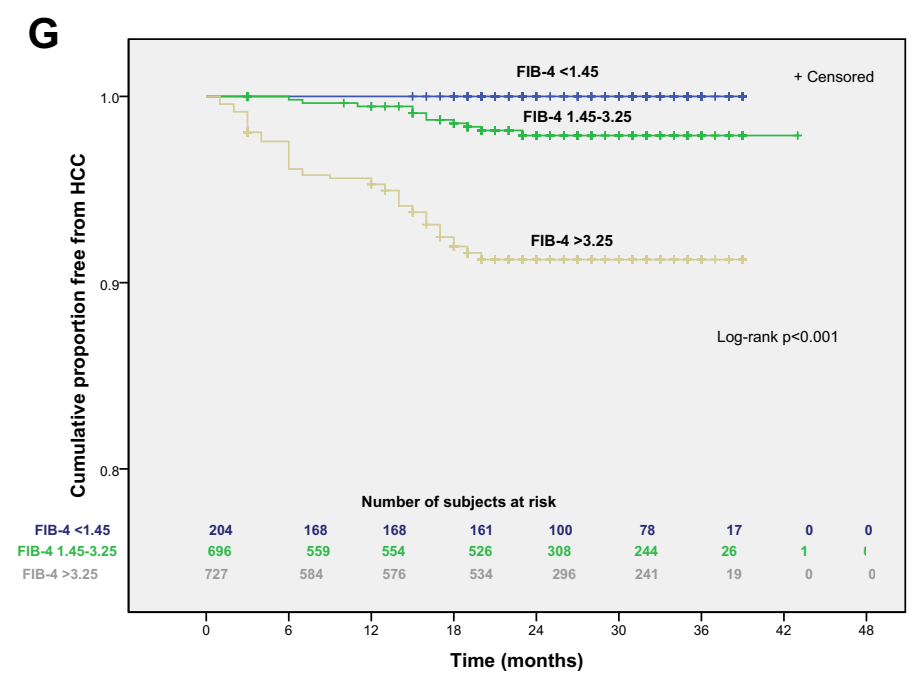

Figure I Curves of cumulative incidence of HCC among patients treated with DAAs and number of patients treated with DAA at risk at different times: overall (A); according to SVR (B); according to fibrosis stage (C); according to CTP (D); according to AFP level (E); according to DM (F); and according to initial FIB-4 score (G).

a total of 2,386 patients estimated the annual rates of decompensation and HCC development in patients with compensated $\mathrm{HCV}$ cirrhosis to be $6.37 \%$ and $3.36 \%$, respectively. $^{25} \mathrm{~A}$ prospective study of 1,254 untreated Egyptian patients with $\mathrm{HCV}$-related cirrhosis estimated annual incidence of $\mathrm{HCC}$ at $5.3 \%{ }^{23}$

With the availability of DAAs, the management of $\mathrm{HCV}$ was revolutionized, and treatment became effective, more tolerable, and safer, even in patients with decompensated cirrhosis. ${ }^{17,26}$

Several studies have recently addressed how DAA therapy alters the risk of HCC development. ${ }^{7,14,15,27,28}$ Cardoso et al reported $\mathrm{HCC}$ occurrence of $7.4 \%$ in 54 patients after 12 months of follow-up after successful IFN- free antiviral therapy for $\mathrm{HCV}$-associated cirrhosis, ${ }^{16}$ and a report from Germany indicated that the short-term risk of HCC development is not reduced in patients with cirrhosis treated with DAAs vs those not treated. ${ }^{29}$ On the other hand, a report from Spain that included data on about 4,000 patients treated with DAAs reported annual HCC incidence of $0.93 \%$ within 18 months of starting DAA therapy. They found higher HCC incidence among patients with cirrhosis, irrespective of response to DAAs. ${ }^{30}$

In this prospective study, 66 of 1,630 patients developed de novo HCC over a follow-up of 3,065.5 PYs, with overall crude incidence of 2.15 per 100 PYs (95\% CI 1.69-2.74). Incidence in patients without cirrhosis (F3 fibrosis) was lower (0.35 per 100 PYs, 95\% CI 0.11- 
Table 3 Incidence of Hepatocellular Cancer in the Whole Cohort

\begin{tabular}{|c|c|c|c|}
\hline \multicolumn{2}{|l|}{ Characteristics } & \multirow{2}{*}{$\begin{array}{c}\begin{array}{c}\text { Follow- } \\
\text { Up } \\
\text { (PYs) }\end{array} \\
773.2\end{array}$} & \multirow{2}{*}{$\begin{array}{c}\begin{array}{c}\text { Incidence } \\
\text { Rate/ I } 00\end{array} \\
\text { PYs (95\% CI) } \\
\text { I.8I (I.07-3.05) }\end{array}$} \\
\hline Age, years & $<50$ & & \\
\hline & $50-<60$ & $1,340.9$ & $2.08(1.44-3.02)$ \\
\hline & $\geq 60$ & 951.4 & $2.52(1.69-3.67)$ \\
\hline \multirow[t]{2}{*}{ Sex } & Male & $2,231.9$ & $2.32(1.77-3.06)$ \\
\hline & Female & 833.6 & I.68 (0.99-2.83) \\
\hline \multirow[t]{2}{*}{ Ascites } & No & $2,882.2$ & $\mathrm{I} .73(\mathrm{I} .3 \mathrm{I}-2.28)$ \\
\hline & Yes & 183.3 & $\begin{array}{c}8.73(5.34- \\
14.25)\end{array}$ \\
\hline \multirow{3}{*}{$\begin{array}{l}\text { Platelet count, } \times 10^{3} / \\
\mathrm{mm}^{3}\end{array}$} & $\geq 150$ & I,555.0 & $0.83(0.48-1.43)$ \\
\hline & $100-<150$ & 948.1 & $2.63(1.78-3.90)$ \\
\hline & $<100$ & 562.4 & $4.97(3.43-7.21)$ \\
\hline \multirow[t]{2}{*}{ AFP, ng/mL } & $<10$ & $1,809.9$ & $0.93(0.58-1.5 \mathrm{I})$ \\
\hline & $\geq 10$ & $1,255.6$ & $3.90(2.94-5.16)$ \\
\hline \multirow[t]{2}{*}{ Diabetes mellitus } & No & $2,505.7$ & 1.44 (I.44-1.99) \\
\hline & Yes & 559.8 & $5.35(3.74-7.66)$ \\
\hline \multirow[t]{2}{*}{ Fibrosis stage } & F3 & 873.3 & $0.33(0.1 \mathrm{I}-\mathrm{I} .0 \mathrm{I})$ \\
\hline & $\mathrm{F} 4$ & $2,192.2$ & $2.90(2.30-3.70)$ \\
\hline \multirow[t]{3}{*}{ CTP ${ }^{a}$} & $A$ & I,804.I & $2.1(1.5-2.9)$ \\
\hline & B & 375.9 & $6.1(4.1-9.0)$ \\
\hline & C & 12.3 & $16.30(4.6-44.1)$ \\
\hline \multirow[t]{2}{*}{$S V R^{b}$} & Yes & $2,866.8$ & 1.91 (1.47-2.49) \\
\hline & No & 196.5 & $\begin{array}{c}5.59(3.10- \\
10.10)\end{array}$ \\
\hline \multirow[t]{3}{*}{ Initial FIB-4 score } & $<1.45$ & 403.8 & $0.34(0.03-1.76)$ \\
\hline & $1.45-3.25$ & $1,308.3$ & I.22 (0.75-I.99) \\
\hline & $>3.25$ & I, 353.4 & $3.62(2.73-4.79)$ \\
\hline FIB-4 score after & $<1.45$ & 856.3 & $0.35(0.32-0.38)$ \\
\hline \multirow[t]{2}{*}{ EOT $^{\mathrm{c}}$} & $1.45-3.25$ & $\mathrm{I}, 085.8$ & $2.76(1.86-3.94)$ \\
\hline & $>3.25$ & 520.1 & $6.34(4.37-8.91)$ \\
\hline \multirow{5}{*}{$\begin{array}{l}\text { Change in FIB-4 } \\
\text { (initial to } \\
\text { posttreatment) }\end{array}$} & $<3.25-$ & $|, 23| .2$ & $0.73(0.33-1.39)$ \\
\hline & $<3.25$ & & \\
\hline & $<3.25-\geq 3.25$ & 138.8 & I.44 (0.17-5.20) \\
\hline & $\geq 3.25-<3.25$ & 712.3 & $3.51(2.27-5.18)$ \\
\hline & $\geq 3.25-\geq 3.25$ & 454.8 & $7.89(5.33-9.41)$ \\
\hline
\end{tabular}

Notes: ${ }^{\text {a }}$ Patients with cirrhosis, not including those with advanced fibrosis; ${ }^{b}$ data missing for two patients; ${ }^{\mathrm{C}} \mathrm{I}, 345$ patients with available FIB-4 scores after EOT. Abbreviations: CTP, Child-Turcotte-Pugh; DAA, directly acting antiviral; EOT, end of treatment; FIB-4, Fibrosis 4 (index); HCC, hepatocellular carcinoma; HCV, hepatitis C virus; SVR, sustained virological response; PYs, person-years.

1.07) than in patients with cirrhosis (2.88 per $100 \mathrm{PYs}$, 95\% CI 2.25-3.69). El Tabbakh et al prospectively followed patients with HCV-related cirrhosis untreated in the same center through a screening program before the availability of DAAs. They found the crude incidence of HCC in untreated patients with HCV-related cirrhosis to be 5.57 per 100 PYs (95\% CI 4.54-6.76). Our data showed a significant reduction in incidence in similar patients receiving DAA therapy (difference 2.69 per 100 PYs, 95\% CI $1.43 \%-3.95 \%)$.

Several studies have found no evidence of increased rates of HCC in patients treated with DAAs compared to IFN-treated patients. ${ }^{31,32}$ Innes et al documented the outcome of 857 patients with HCV who were treated with IFN-based or IFN-free regimens over 2.4 years' follow-up. HCC occurrence was doubled (2.53 vs 1.26 per 100 PYs) in patients who had been treated with DAAs. However, patients treated with DAAs were older and at higher Child-Pugh classes than patients treated with IFN-based regimens. With correction of the confounders, there was no difference between the two treatment regimens in terms of HCC occurrence (AHR 1.15, 95\% CI 0.49-2.71). ${ }^{31}$

Our results indicate that the risk of developing HCC is higher during the first 18 months after antiviral therapy, suggesting that those patients might already have had microscopic HCC foci before the start of antiviral therapy. Mettke et al found that DAA therapy did not alter the short-term risk of HCC in DAA-treated vs untreated patients with HCVrelated liver cirrhosis, although reduced HCC incidence may become evident after $>15$ months of DAA therapy. ${ }^{29}$

In the present study, several risk factors of HCC development after DAA treatment were identified. Patients with cirrhosis had significantly higher incidence of HCC than patients with advanced fibrosis, and risk increased with increased severity of cirrhosis assessed by CTP class. Also, we found that worsening of pretreatment FIB-4 scores after therapy was associated with increased risk, and improvement of pretreatment FIB-4 scores after the end of therapy was associated with a reduction in risk of $\mathrm{HCC}$ development. The risk factors identified are indicators of more advanced liver disease, which highlights the need for early treatment of $\mathrm{HCV}$, preferably before cirrhosis is established.

Treatment failure was an important risk factor of HCC occurrence. The annual incidence of HCC in patients who achieved SVR was 1.91 per 100 PYs (95\% CI 1.47-2.49), significantly lower than the 5.59 per 100 PYs $(95 \%$ CI 3.1-10.1) incidence in patients without SVR. Incidence in patients who did not respond to therapy was similar to the historical incidence in patients with untreated cirrhosis.

Our data agree with the results of several large studies. ${ }^{33-35}$ A study of 129 Veterans Administration hospitals in the United 
Table 4 Factors Associated with Occurrence of HCC: Cumulative Probabilities of HCC Occurrence and Univariate Analysis

\begin{tabular}{|c|c|c|c|c|c|c|c|}
\hline Variable Category & & $\mathbf{n}$ & $\begin{array}{c}\text { HCC } \\
\text { Occurrence, } \\
\text { n }\end{array}$ & $\begin{array}{l}\text { Cumulative Probability of } \\
\text { HCC Occurrence (\%) }\end{array}$ & $P$ & $\begin{array}{c}\text { Univariate } \\
\text { Hazard Ratio } \\
(95 \% \mathrm{Cl})\end{array}$ & $P$ \\
\hline Age, years & $\begin{array}{l}<50 \\
50-<60 \\
\geq 60\end{array}$ & $\begin{array}{l}410 \\
706 \\
514\end{array}$ & $\begin{array}{l}14 \\
28 \\
24\end{array}$ & $\begin{array}{l}4.5 \\
4.7 \\
5.3\end{array}$ & 0.43 & $\begin{array}{c}\text { I (reference) } \\
\text { I.II }(0.59-2.1 \mathrm{I}) \\
\mathrm{I} .30(0.67-2.50)\end{array}$ & $\begin{array}{l}0.75 \\
0.44\end{array}$ \\
\hline Sex & $\begin{array}{l}\text { Male } \\
\text { Female }\end{array}$ & $\begin{array}{c}1,185 \\
445\end{array}$ & $\begin{array}{l}52 \\
14\end{array}$ & $\begin{array}{l}5.2 \\
3.8\end{array}$ & 0.25 & $\begin{array}{c}\text { I (reference) } \\
0.7 \mid(0.39-1.27)\end{array}$ & 0.25 \\
\hline CTP score ${ }^{a}$ & $\begin{array}{l}A \\
B \\
C\end{array}$ & $\begin{array}{c}973 \\
217 \\
9\end{array}$ & $\begin{array}{c}38 \\
23 \\
2\end{array}$ & $\begin{array}{l}4.7 \\
11.9 \\
23.8\end{array}$ & $<0.001$ & $\begin{array}{c}1 \text { (reference) } \\
2.69(1.60-4.52) \\
6.45(1.56-26.75)\end{array}$ & $\begin{array}{l}<0.001 \\
0.003\end{array}$ \\
\hline Ascites & $\begin{array}{l}\text { No } \\
\text { Yes }\end{array}$ & $\begin{array}{l}1,518 \\
112\end{array}$ & $\begin{array}{l}50 \\
16\end{array}$ & $\begin{array}{l}4.0 \\
14.6\end{array}$ & $<0.001$ & $\begin{array}{c}\text { I (reference) } \\
4.05(2.3 \mid-7.12)\end{array}$ & $<0.001$ \\
\hline Platelet count, $\times 10^{3} / \mathrm{mm}^{3}$ & $\begin{array}{l}\geq 150 \\
100-<150 \\
<100\end{array}$ & $\begin{array}{l}808 \\
503 \\
319\end{array}$ & $\begin{array}{l}13 \\
25 \\
28\end{array}$ & $\begin{array}{c}1.9 \\
6.0 \\
10.1\end{array}$ & $<0.001$ & $\begin{array}{c}\text { I (reference) } \\
3.08(1.57-6.02) \\
5.37(2.78-10.38)\end{array}$ & $\begin{array}{r}0.001 \\
<0.001\end{array}$ \\
\hline AFP, ng/mL & $\begin{array}{l}<10 \\
\geq 10\end{array}$ & $\begin{array}{l}905 \\
725\end{array}$ & $\begin{array}{l}17 \\
49\end{array}$ & $\begin{array}{l}2.2 \\
8.2\end{array}$ & $<0.001$ & $\begin{array}{c}\text { I (reference) } \\
3.82(2.20-6.63)\end{array}$ & $<0.001$ \\
\hline Diabetes & $\begin{array}{l}\text { No } \\
\text { Yes }\end{array}$ & $\begin{array}{c}1324 \\
306\end{array}$ & $\begin{array}{l}36 \\
30\end{array}$ & $\begin{array}{c}3.2 \\
12.0\end{array}$ & 0.001 & $\begin{array}{c}\text { I (reference) } \\
3.62(2.23-5.88)\end{array}$ & $<0.001$ \\
\hline$S V R^{b}$ & $\begin{array}{l}\text { Yes } \\
\text { No }\end{array}$ & $\begin{array}{c}1531 \\
97\end{array}$ & $\begin{array}{l}55 \\
11\end{array}$ & $\begin{array}{l}4.3 \\
13.1\end{array}$ & $<0.001$ & $\begin{array}{c}1 \text { (reference) } \\
3.18(1.67-6.08)\end{array}$ & $<0.001$ \\
\hline Fibrosis stage & $\begin{array}{l}\text { F3 } \\
\text { F4 }\end{array}$ & $\begin{array}{l}431 \\
1199\end{array}$ & $\begin{array}{c}3 \\
63\end{array}$ & $\begin{array}{l}0.8 \\
6.2\end{array}$ & $<0.001$ & $\begin{array}{c}\text { I (reference) } \\
7.28(2.29-23.19)\end{array}$ & 0.001 \\
\hline Initial FIB-4 score & $\begin{array}{l}<1.45 \\
1.45-3.25 \\
>3.25\end{array}$ & $\begin{array}{l}205 \\
697 \\
728\end{array}$ & $\begin{array}{l}1 \\
16 \\
49\end{array}$ & $\begin{array}{l}0.5 \\
2.9 \\
7.9\end{array}$ & $<0.001$ & $\begin{array}{c}\text { I (reference) } \\
4.85(0.64-36.56) \\
14.23(1.97-103.04)\end{array}$ & $\begin{array}{l}0.13 \\
0.009\end{array}$ \\
\hline $\begin{array}{l}\text { Change in FIB-4 score }>3.25 \\
\text { with treatment }(n=609)\end{array}$ & $\begin{array}{l}<3.25 \text { after } \\
\text { treatment } \\
>3.25 \text { after } \\
\text { treatment }\end{array}$ & $\begin{array}{l}386 \\
223\end{array}$ & $\begin{array}{l}25 \\
30\end{array}$ & $\begin{array}{l}7.9 \\
14.3\end{array}$ & 0.015 & $\begin{array}{c}\text { I (reference) } \\
1.91 \text { (I.12-3.25) }\end{array}$ & 0.017 \\
\hline
\end{tabular}

Notes: ${ }^{a}$ Patients with cirrhosis, not including those with advanced fibrosis; ' two patients died before SVRI2.

Abbreviations: CTP, Child-Turcotte-Pugh; EOT, end of treatment; FIB-4, Fibrosis 4 (index); HCC, hepatocellular carcinoma; HCV, hepatitis C virus; SVR, sustained virological response.

States, where $40 \%$ had cirrhosis before treatment, confirmed a considerable reduction in risk of $\mathrm{HCC}$ in patients with DAAinduced SVR compared to patients with treatment failure or no treatment (0.90 vs 3.45 HCC per $100 \mathrm{PYs}$, AHR 0.28, 95\% CI $0.22-0.36) .{ }^{33}$ Similarly, a prospective study on 2,249 patients with $\mathrm{HCV}$-associated cirrhosis compared the risk of developing HCC based on liver reserve and SVR status after DAA therapy over 1 year's follow up. In patients with CTP class A, HCC developed in $2.1 \%$ of patients with SVR and $6.6 \%$ of patients without SVR, while in patients with decompensated cirrhosis, the risk was $7.8 \%$ in patients with SVR and $12.4 \%$ in patients with treatment failure. ${ }^{34}$ Ioannou et $\mathrm{al}^{28}$ reviewed data of 62,354 HCV patients and identified 3,271 incident HCC cases diagnosed after DAA therapy. The highest incidence was found in patients with cirrhosis and treatment failure (3.25 per 100 PYs), followed by patients with cirrhosis and SVR (1.97 per 100 PYs), absence of cirrhosis with treatment failure (0.87 per $100 \mathrm{PYs}$ ), and patients who achieved SVR in absence of cirrhosis ( 0.24 per $100 \mathrm{PYs})$. El-Serag et al reported that the risk of $\mathrm{HCC}$ after $\mathrm{HCV}$ cure, though considerably reduced, remained relatively high $-0.33 \%$ per year - and that older age and/or presence of cirrhosis at the time of SVR 
Table 5 Multivariate Analysis of Factors Associated with Occurrence of HCC

\begin{tabular}{|l|c|c|}
\hline & AHR $(95 \% \mathbf{~ C I})^{\mathbf{a}}$ & $\boldsymbol{P}$ \\
\hline CTP >A & $2.77(1.76-4.36)$ & $<0.001$ \\
AFP > I0 & $3.46(1.96-6.11)$ & $<0.001$ \\
No SVR & $2.76(1.39-5.48)$ & 0.004 \\
Diabetes & $3.20(1.94-5.28)$ & $<0.001$ \\
FIB-4 score & $3.59(1.10-11.66)$ & 0.03 \\
\hline
\end{tabular}

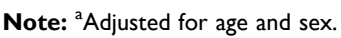

Abbreviations: CTP, Child-Turcotte-Pugh; EOT, end of treatment; FIB-4, Fibrosis 4 (index); HCC, hepatocellular carcinoma; HCV, hepatitis C virus; SVR, sustained virological response.

were associated with a high-enough risk to warrant continued surveillance. ${ }^{36}$ Similarly to our findings, Wu et al reported that risk factors of HCC in patients who achieved SVR were older age, presence of liver cirrhosis, higher pre- and posttreatment AFP, and high posttreatment AST:platelet ratio index, and that patients with persistently high AFP ( $\geq 15 \mathrm{ng} / \mathrm{mL})$ and AST: platelet ratio index $(\geq 0.7)$ before and after treatment had the highest incidence of HCC development. ${ }^{37}$

The main limitation of the study is that the untreated comparator cohort was a historical one of patients with HCV-related cirrhosis in the same location followed up and reported 5 years earlier. Also, the possibility of the presence of preexisting small HCCs at the beginning of DAA therapy cannot be excluded. Although all patients were examined by ultrasound before starting therapy and a small group by multidetector triphasic CT scans, even if all had been examined by CT or MRI, the possibility of the preexistence of small HCCs cannot be excluded. Had such lesions been present and detected, this would decrease even further the incidence of de novo HCC developing after DAA therapy.

\section{Conclusion}

Our data show that over a relatively long follow-up, the incidence of HCC following SVR induced by DAA therapy in patients with HCV-G4 was lowered in patients with advanced fibrosis and cirrhosis.

Although we found that the risk of HCC following DAA therapy was reduced in patients with cirrhosis who responded to treatment, our results showed much lower incidence in patients with advanced fibrosis and indicate the necessity of treating all patients with $\mathrm{HCV}$ infection, and preferably early treatment before the development of cirrhosis.

Also, our results indicate the necessity of following up patients with cirrhosis and SVR with close surveillance for the development of $\mathrm{HCC}$, and more so for patients who do not achieve SVR (in whom incidence of HCC is not reduced and remains similar to untreated patients).

\section{Abbreviations}

ALT, alanine aminotransferase; AST, aspartate aminotransferase; CTP, Child-Turcotte-Pugh; DAA, directly acting antiviral; Dcv, daclatasvir; HCC, hepatocellular carcinoma; HCV-G4, HCV genotype 4; Ldv, ledipasvir; R, ritonavir; Rbv, ribavirin; Smv, simeprevir; Sof, sofosbuvir; SVR, sustained virological response.

\section{Ethics}

The authors are accountable for all aspects of the work in ensuring that questions related to the accuracy or integrity of any part of the work are appropriately investigated and resolved.

This trial was conducted in accordance with the Declaration of Helsinki (as revised in 2013). The study was approved by the institutional review board of the National Liver Institute (IRB00003413), and informed consent was obtained from all participants.

\section{Disclosure}

Not related to this work, IW has served as a speaker for Hoffman La Roche, Merck, Gilead, and AbbVie, served on advisory boards for Astra-Zeneca, Lilly, Merck, and Eva Pharma, been principal investigator in clinical trials for AbbVie, Marcyrl, MenaPharm, Novartis, and Pharco, and has received nonfinancial support from Eva Pharma, and MenaPharma, MSD outside the submitted work. The authors report no other conflicts of interest in this work.

\section{References}

1. Li DK, Chung RT. Impact of hepatitis C virus eradication on hepatocellular carcinogenesis. Cancer. 2015;121(17):2874-2882. doi:10.10 02/cncr.29528

2. Bruix J, Sherman M. Management of hepatocellular carcinoma: an update. Hepatology. 2011;53(3):1020-1022. doi:10.1002/hep.24199

3. D'amico G, Pasta L, Morabito A, et al. Competing risks and prognostic stages of cirrhosis: a 25-year inception cohort study of 494 patients. Aliment Pharmacol Ther. 2014;39(10):1180-1193. doi:10.11 11/apt.12721

4. Hassan MM, Hwang L-Y, Hatten CJ, et al. Risk factors for hepatocellular carcinoma: synergism of alcohol with viral hepatitis and diabetes mellitus. Hepatology. 2002;36(5):1206-1213. doi:10.1053/jhep.2002.36780

5. Baumert TF, Jühling F, Ono A, Hoshida Y. Hepatitis C-related hepatocellular carcinoma in the era of new generation antivirals. BMC Med. 2017;15(1):52. doi:10.1186/s12916-017-0815-7

6. Chang K-C, Hung C-H, Lu S-N, et al. A novel predictive score for hepatocellular carcinoma development in patients with chronic hepatitis $\mathrm{C}$ after sustained response to pegylated interferon and ribavirin combination therapy. J Antimicrob Chemother. 2012;67(11):27 66-2772. doi:10.1093/jac/dks269 
7. van der Meer AJ, Veldt BJ, Feld JJ, et al. Association between sustained virological response and all-cause mortality among patients with chronic hepatitis $\mathrm{C}$ and advanced hepatic fibrosis. JAMA. 2012;308(24):2584-2593. doi:10.1001/jama.2012.144878

8. Chung RT, Baumert TF. Curing chronic hepatitis C-the arc of a medical triumph. $N$ Engl $J$ Med. 2014;370(17):1576-1578. doi:10.1056/NEJMp1400986

9. Elsharkawy A, Fouad R, El Akel W, et al. Sofosbuvir-based treatment regimens: real life results of 14409 chronic $\mathrm{HCV}$ genotype 4 patients in Egypt. Aliment Pharmacol Ther. 2017;45(5):681-687. doi:10.1111/ apt.13923

10. Doss W, Esmat G, El-Serafy M, et al. Real-life results of sofosbuvir based therapy for Egyptian patients with hepatitis $\mathrm{C}$ and advanced fibrosis-cirrhosis. J Hepatol. 2016;64(2):S772. doi:10.1016/S01688278(16)01505-1

11. Elsharkawy A, El-Raziky M, El-Akel W, et al. Planning and prioritizing direct-acting antivirals treatment for $\mathrm{HCV}$ patients in countries with limited resources: lessons from the Egyptian experience. $J$ Hepatol. 2018;68(4):691-698. doi:10.1016/j. jhep.2017.11.034

12. Pawlotsky J-M, Negro F, Aghemo A, et al. EASL recommendations on treatment of hepatitis C 2018. J Hepatol. 2018;69 (2):461-511.

13. Backus LI, Belperio PS, Shahoumian TA, Mole LA. Impact of sustained virologic response with direct-acting antiviral treatment on mortality in patients with advanced liver disease. Hepatology. 2019;69(2):487-497. doi:10.1002/hep.29408

14. Conti F, Buonfiglioli F, Scuteri A, et al. Early occurrence and recurrence of hepatocellular carcinoma in HCV-related cirrhosis treated with direct-acting antivirals. $J$ Hepatol. 2016;65(4):727-733. doi:10.1016/j.jhep.2016.06.015

15. Kozbial K, Moser S, Schwarzer R, et al. Unexpected high incidence of hepatocellular carcinoma in cirrhotic patients with sustained virologic response following interferon-free direct-acting antiviral treatment. $J$ Hepatol. 2016;65(4):856-858. doi:10.1016/j. jhep.2016.06.009

16. Cardoso H, Vale AM, Rodrigues S, et al. High incidence of hepatocellular carcinoma following successful interferon-free antiviral therapy for hepatitis C associated cirrhosis. J Hepatol. 2016;65 (5):1070-1071. doi:10.1016/j.jhep.2016.07.027

17. Cheung MC, Walker AJ, Hudson BE, et al. Outcomes after successful direct-acting antiviral therapy for patients with chronic hepatitis C and decompensated cirrhosis. J Hepatol. 2016;65(4):741-747. doi:10.1016/j.jhep.2016.06.019

18. El Kassas M, Funk A, Salaheldin M, et al. Increased recurrence rates of hepatocellular carcinoma after DAA therapy in a hepatitis Cinfected Egyptian cohort: a comparative analysis. J Viral Hepat. 2018;25(6):623-630. doi:10.1111/jvh.12854

19. Sterling RK, Lissen E, Clumeck N, et al. Development of a simple noninvasive index to predict significant fibrosis in patients with HIV/ HCV coinfection. Hepatology. 2006;43(6):1317-1325. doi:10.1002/ hep. 21178

20. Vallet-Pichard A, Mallet V, Nalpas B, et al. FIB-4: an inexpensive and accurate marker of fibrosis in HCV infection. comparison with liver biopsy and fibrotest. Hepatology. 2007;46(1):32-36. doi:10.1002/ hep. 21669

21. Castera L, Forns X, Alberti A. Non-invasive evaluation of liver fibrosis using transient elastography. $J$ Hepatol. 2008;48 (5):835-847. doi:10.1016/j.jhep.2008.02.008

22. Llovet J, Ducreux M, Lencioni R, Di Bisceglie A, Galle P, Dufour J. European Association for the Study of the Liver European Organisation for Research and Treatment of Cancer: EASL-EORTC clinical practice guidelines: management of hepatocellular carcinoma. J Hepatol. 2012;56(4):908-943.
23. Eltabbakh M, Zaghla H, Abdel-Razek W, et al. Utility and cost-effectiveness of screening for hepatocellular carcinoma in a resource-limited setting. Med Oncol. 2015;32(1):432. doi:10.1007/ s12032-014-0432-7

24. El-Serag HB. Hepatocellular carcinoma. N Engl J Med. 2011;365 (12):1118-1127. doi:10.1056/NEJMra1001683

25. Alazawi W, Cunningham M, Dearden J, Foster GR. Systematic review: outcome of compensated cirrhosis due to chronic hepatitis C infection. Aliment Pharmacol Ther. 2010;32(3):344-355. doi:10.1111/j.1365-2036.2010.04370.x

26. Nahon P, Bourcier V, Layese R, et al. Eradication of hepatitis C virus infection in patients with cirrhosis reduces risk of liver and non-liver complications. Gastroenterology. 2017;152(1):142-156. e142. doi:10.1053/j.gastro.2016.09.009

27. Reig M, Mariño Z, Perelló C, et al. Unexpected high rate of early tumor recurrence in patients with HCV-related HCC undergoing interferon-free therapy. $J$ Hepatol. 2016;65(4):719-726. doi:10.1016/j.jhep.2016.04.008

28. Ioannou GN, Green PK, Berry K. HCV eradication induced by direct-acting antiviral agents reduces the risk of hepatocellular carcinoma. $J$ Hepatol. 2018;68(1):25-32. doi:10.1016/j. jhep.2017.08.030

29. Mettke F, Schlevogt B, Deterding K, et al. Interferon-free therapy of chronic hepatitis $\mathrm{C}$ with direct-acting antivirals does not change the short-term risk for de novo hepatocellular carcinoma in patients with liver cirrhosis. Aliment Pharmacol Ther. 2018;47(4):516-525. doi:10.1111/apt.14427

30. Calleja JL, Crespo J, Rincon D, et al. Effectiveness, safety and clinical outcomes of direct-acting antiviral therapy in HCV genotype 1 infection: results from a Spanish real-world cohort. J Hepatol. 2017;66(6):1138-1148. doi:10.1016/j.jhep.2017.01.028

31. Innes H, Barclay ST, Hayes PC, et al. The risk of hepatocellular carcinoma in cirrhotic patients with hepatitis $\mathrm{C}$ and sustained viral response: role of the treatment regimen. $J$ Hepatol. 2018;68 (4):646-654. doi:10.1016/j.jhep.2017.10.033

32. Rutledge SM, Zheng H, Li DK, Chung RT. No evidence for higher rates of hepatocellular carcinoma after direct-acting antiviral treatment: a meta-analysis. Hepatoma Res. 2019;5. doi:10.20517/23945079.2019.19

33. Kanwal F, Kramer J, Asch SM, Chayanupatkul M, Cao Y, El-Serag HB. Risk of hepatocellular cancer in HCV patients treated with direct-acting antiviral agents. Gastroenterology. 2017;153(4):9961005. e1001. doi:10.1053/j.gastro.2017.06.012

34. Calvaruso V, Cabibbo G, Cacciola I, et al. Incidence of hepatocellular carcinoma in patients with $\mathrm{HCV}$-associated cirrhosis treated with direct-acting antiviral agents. Gastroenterology. 2018;155(2):411421. e414. doi:10.1053/j.gastro.2018.04.008

35. Ogawa E, Furusyo N, Nomura H, et al. Short-term risk of hepatocellular carcinoma after hepatitis $\mathrm{C}$ virus eradication following directacting anti-viral treatment. Aliment Pharmacol Ther. 2018;47 (1):104-113. doi:10.1111/apt.14380

36. El-Serag HB, Kanwal F, Richardson P, Kramer J. Risk of hepatocellular carcinoma after sustained virological response in Veterans with hepatitis C virus infection. Hepatology. 2016;64(1):130-137. doi:10.1002/hep. 28535

37. Wu CK, Chang $\mathrm{KC}$, Hung $\mathrm{CH}$, et al. Dynamic alpha-fetoprotein, platelets and AST-to-platelet ratio index predict hepatocellular carcinoma in chronic hepatitis $\mathrm{C}$ patients with sustained virological response after antiviral therapy. $J$ Antimicrob Chemother. 2016;71 (7):1943-1947. doi:10.1093/jac/dkw097 


\section{Publish your work in this journal}

The Journal of Hepatocellular Carcinoma is an international, peerreviewed, open access journal that offers a platform for the dissemination and study of clinical, translational and basic research findings in this rapidly developing field. Development in areas including, but not limited to, epidemiology, vaccination, hepatitis therapy, pathology

and molecular tumor classification and prognostication are all considered for publication. The manuscript management system is completely online and includes a very quick and fair peer-review system, which is all easy to use. Visit http://www.dovepress.com/ testimonials.php to read real quotes from published authors.

Submit your manuscript here: https://www.dovepress.com/journal-of-hepatocellular-carcinoma-journal 